\title{
Anne-Élisabeth Halpern, «Il se croit Maldoror» et il n'a pas tort
}

\section{Marina Mattera}

\section{(2) OpenEdition}

1 Journals

\section{Edizione digitale}

URL: http://journals.openedition.org/studifrancesi/7023

DOI: 10.4000/studifrancesi.7023

ISSN: 2421-5856

\section{Editore}

Rosenberg \& Sellier

\section{Edizione cartacea}

Data di pubblicazione: 1 septembre 2010

Paginazione: 404-405

ISSN: 0039-2944

\section{Notizia bibliografica digitale}

Marina Mattera, «Anne-Élisabeth Halpern, «ll se croit Maldoror» et il n'a pas tort», Studi Francesi [Online], 161 (LIV | II) | 2010, online dal 30 novembre 2015, consultato il 11 janvier 2021. URL: http:// journals.openedition.org/studifrancesi/7023 ; DOI: https://doi.org/10.4000/studifrancesi.7023

Questo documento è stato generato automaticamente il 11 janvier 2021.

\section{(c) (i) (9)}

Studi Francesi è distribuita con Licenza Creative Commons Attribuzione - Non commerciale - Non opere derivate 4.0 Internazionale. 


\title{
Anne-Élisabeth Halpern, «Il se croit Maldoror» et il n'a pas tort
}

\author{
Marina Mattera
}




\section{NOTIZIA}

ANNE-ÉLISABETH HALPERN, «Il se croit Maldoror» et il n'a pas tort, in Affinités électives, sous la direction de Gérard FARASSE, «Revue des Sciences Humaines», 292, octobre-décembre 2008, pp. 41-60.

1 Questo breve articolo prende in esame l'opera di Michaux nella fitta trama di relazioni che legano lo scrittore a Isidore Ducasse, meglio noto sotto lo pseudonimo di Lautréamont: come suggerito nel titolo, l'A. focalizza infatti la propria attenzione sul primo testo della nota trilogia intitolata Cas de folie circulaire (1922), la cui diffusione esordio dello scrittore sulla scena letteraria-esemplifica in modo inequivocabile l'influenza che l'autore dei Chants de Maldoror ha esercitato nei confronti dell'allora giovane Michaux. La lettura di Lautréamont, il cui successo-tardivo-è legato al fervente entusiasmo di Max Waller, fondatore della «Jeune Belgique», seduce Michaux al punto tale - affermerà egli stesso - da ispirare in lui una fervente e creativa vena artistica.

2 L'A. sottolinea la dimensione trasgressiva che pervade l'opera di Michaux, per il quale Lautréamont fornisce un perfetto esempio di radicale anti-conformismo letterario: come quest'ultimo, lo scrittore belga cercherà con ogni mezzo di liberarsi da ogni forma di sapere istituzionalizzato.

3 Tuttavia - ed è questo il punto focale dell'articolo - l'adorazione quasi ossessiva nutrita da Michaux nei confronti di Isidore si trasforma ben presto in un deliberato tentativo di distacco, chiave di volta del Cas de folie circulaire. Lo scrittore rinnega e abbandona il suo modello, staccandosene come il frutto dall'albero, afferma l'A. che conclude parodiando sagacemente il titolo dell'opera: «Il ne se croit plus Maldoror». 